\title{
Food plants of burnets (Zygaena F.. Lepidopt., Zygaenidae) and the dying-out of these moths in the Pieniny Mts. (Poland)
}

KAZIMIER7 7ARZYCKI*, JERZY S. DABROWSKI**

* Institute of Botany. Polish Academy of Sciences, Lubicz 46, 31-512 Kraków. Poland ** Grabowskiego 8/4. 31-126 Kraków. Poland

(Received: January 13.1986. Accepted: March 7. 1986)

\begin{abstract}
The resources of food plants of both the Zygaena F. larvae and imagines are still fairly large in the Pieniny Mts. and Małopolska Upland (Wyżyna Małopolska). but they shrink rapidly in connection with urbanization and the intensification of agriculture. In 1982-1985 the populations of Zygaena angelicae Ochsen.. Z. loti (Den. et Schiff.). Z. filipendulae (L.). Z. Ionicerae (Schev.). Z. viciae (Den. et Schiff.). and $\%$. purpuralis (Bünn.) incl. Z. minos (Den et Schiff.) have been observed. 5 species (Zygaena brizae (Esp.). Z. cynarae (Esp.). Z. ephialtes (L.). Z. osterodensis Reiss and Z. trifolii (Esp.)) observed in the Pieniny Mts. in 1950-1960 are extinct. The decrease in the number of Zygaena species and in the size of their populations in the Pieniny Mts. and other regions of this country is caused by changes occurring in biotopes. The dying-out of moths and butterflies in the Pieniny Mts. can be stopped by a conservation of the biotopes characteristic of this region: the overgrowth of clearings and xerothermic plant associations should be prevented. meadows should be mown late in summer (August) and the use of mineral fertilizers. and insecticides and herbicides should be reduced to a minimum in the Pieniny National Park and at its borders.
\end{abstract}

Key words: Zygaena $F$., moths, food plants, conservation

\section{INTRODUCTION}

In many European countries, including Poland, a rapid extinction of many plants and animals has been observed in recent years. Among other authors Dąbrowski (1982) writes about the shrinkage of a population of Parnassius apollo L. and the dying-out of Zygaena F. species in the Pieniny National Park (PNP). The hypothesis that one of the causes of the dying-out of these moths in the Pieniny Mts. may be a decrease in the resources of food plants indispensable for their development has been considered. 
The aim of this study were:

1. to estimate the up-to-date resources of food-plants of both larvae and imagines of Zygaena species in the PNP and, for comparative purposes. in the Małopolska Uplands;

2. to establish the present-day specific composition and abundance of burnets in various biotopes of the PNP;

3. to make up a list of the Zygaena species observed in the Pieniny Mts. in the fifties of this century which could not be found there lately;

4. to carry out a close analysis of the presumbale causes of the decrease in the abundance of the Zygaena species in the Pieniny Mts. and those of their withdrawal from them;

5. to suggest the measures which might stop the process of vanishing of the lepidopterous fauna from areas under conservation.

\section{AREA AND METHODS}

Field studies were carried out mainly in the area of the PNP and at its borders.

The Pieniny Mts. are a small mountin range. rising $425-982 \mathrm{~m}$ a.s.l. in the south of Poland. They are mainly composed of Jurassic and Cretaceous formations, very diverse as regards petrography. Besides limestones. there are slates, sandstones, conglomerates, etc. there.

The Pieniny Mts. are characterized by a relatively, warm and dry climate, with mean annual temperatures of $6.3-4.5^{\circ} \mathrm{C}$ and the mean annual precipitation is $690-850 \mathrm{~mm}$ (Kostrakiewicz 1982). Descriptions of the meadow and xerothermic plant associations in the Pieniny Mts. are given in a number of papers (Kinasz 1976. Pancer-Kotejowa 1977. Dzwonko and Grodzińska 1979).

Here meadows and xerothermic plant associations occupy an area of above 300 ha, of which approximately only a third, within the bounds of the Central Pieniny Mts., is not subjected to intensive agricultural measures (mineral fertilization, early mowing, ploughing and sowing grass).

The numbers of moths (imagines) were determined in elected sites in 1982-1985. Owing to unfavourable weather conditions, we failed to attain sufficiently representative data in 1984. The following biotopes were included: 1) arable fiedls on the northern slopes of the Pieniny Mts.. in the proximity of the PNP; 2) intensively utilized meadows, including boundary strips of the green and banks close to the borders of the PNP; 3) mesophilous meadows (Anthylli-Trifolietum association). moderately leached brown soile, situated mainly on the northern slopes of the Pieniny Mts. 
sites in the PNP: Doliny above Gródek, Stolarzówka Glade. Kurnikówka Glade. meadows at the foot of the mountains, north of Nowa Gora. and the meadow below the Szopka Pass (in the south); 4) xerothermic associations (Origano-Brachypodietum) on rich marly soils on the southern slopes of the Pieniny Mts.; sites: below the castle ruins at Czorsztyn, Cisowiec. Podskalnia Mt. and Sobczański Ravine. Wet meadows peatbogs and other biotopes investigated by lepidopterologists in the past were repeatedly inspected in the period of flying moths. The number of flying and foraging moths was determined (1-4 times) on a stand, 400-1000 sa.m. in area, in 10 minutes' counts (in 1982 the imagines were counted for 15 minutes, next the results were converted for 10 minutes' counts and rounded up). Observations were made from 10 am till 5 pm, in sunny calm weather, in the second half of July.

Observations of imagines foraging for flower nectar of identified plant species were carried out also outside the Pieniny Mts. in the Małopolska Uplands, chiefly in the reserves of xerothermic vegetation in the Miechow region and near Mydlniki as well as in wet meadows in the region of Dulowa. A stop-watch was used to measure the time of foraging.

The taxonomy, distribution and biology of the Polish Zygaena species are fairly well known (Dąbrowski 1965 and literature quoted). The imagines fly most effectively from $10 \mathrm{am}$ to $4 \mathrm{pm}$ on sunny days from the end of June throughout August. Marked specimens (Dąbrowski 1959) were either recovered in the small biotope area where they had been released or caught not far off (up to $250 \mathrm{~m}$ ), exceptionally only somewhat farther (600 and $900 \mathrm{~m})$.

A list of food-plants of Zygaena larvae has been compiled on the basis of available literature (Blaschke s.a., Blab and Kudrna 1982. Holik 1953, Koch 1964). Basing on own field study and the literature of the subject (Grodzińska 1976, Zarzycki 1981, Michalik 1978, Flóra Slovenska 1966-1984), K. Zarzycki has made a general assessment of the resources of these plants in the Pieniny Mts. and Małopolska Uplands.

A decrease in the number of Zygaena species in the Pieniny Mts. can be traced thanks to studies carried out in this region since the second half of the 19th century (Nowicki 1870. Sitowski 1906, 1910. Błeszyński et al. 1965 Dabrowski 1965, 1982). 
RESULTS

FOOD-PLANTS OF TYGAENA LARVAE

Table 1 shows that the larvae of most Zygaena species feed on plants of the family Papilionaceae more rarely those of Umbelliferae Labiatae and Compositae. The resources of these plants are generally fairly large in the Pieniny Mts. and in the Małopolska Uplands even though they undergo a constant decrease in connection with the progressive intensification of agriculture. This is very conspicuous in the western part of the PNP.

FOOD-PLANTS OF TYGAE I IMAGINIS

The imagines of burnet-moths forage above all for flowers of the plants of the families Dipsacaceae (Knautia arvensis* Scabiosa ochroleuca $S$. lucida etc.) Compositae (chiefly species of the genera Centaurca Carduus and Cirsium) and Labiatae (Salvia verticillata). A list of plants whose flowers are visited by burnet imagines in southern Poland includes above 30 species. Burnet-moths visit violet purple and red flowers they do not avoid yellow ones but were exceptionally seen on blue and white flowers. They evidently avoid the flowers of Melitotus sp. and Ononis arvensis. The plants foraged for by the imagines of burnets are generally speaking still common both in the Pieniny Mts. and in the Małopolska Uplands and other regions of this country.

SPECIFIC COMPOSITION AND ABUNDANCE OF TYGAEA, IMACINES IN IARIOUS BIOTOPFS OI IHF PXP IN $1982-1085$

The specific composition and abundance of these moths in the area of the PNP and on its borders are given in Table $;$ and Fig. 1. No burnet-moths are observed flying over cultivated fields at all. they can sporadically be met with along balks and roadside banks in abundantly fertilized meadows. The greatest number of species are grouped in poorly fertilized mesophilous meadows (Anthylli-Trifolietum association) in the Central Pieniny Mts. inside the PNP. Here were observed: Zygaena lonicerae (Schev.) and $Z$. filipendulae (L.). up to 28 moths per $10 \mathrm{~min}$.. the less abundantly occuring $Z$. viciae (Den. et Schiff.). up to 10 moths per $10 \mathrm{~min}$. and. sporadically, Z. loti (Den. et Schiff.) Z. purpuralis (Brünn.) and $Z$. angelicae Ochsen. This pattern recurred in 3 consecutive seasons. At that time no tendency was reveled for the numbers to decrease. Thermophilous species group on the southern slopes of the Pieniny

* As regards nomenclature we follow Ehrendorfer (1973) (sec Tables 1 and 2). 
Table 1

A list of food-plants of Zygaena larvae in the Pieniny Mts. and Małopolska Uplands

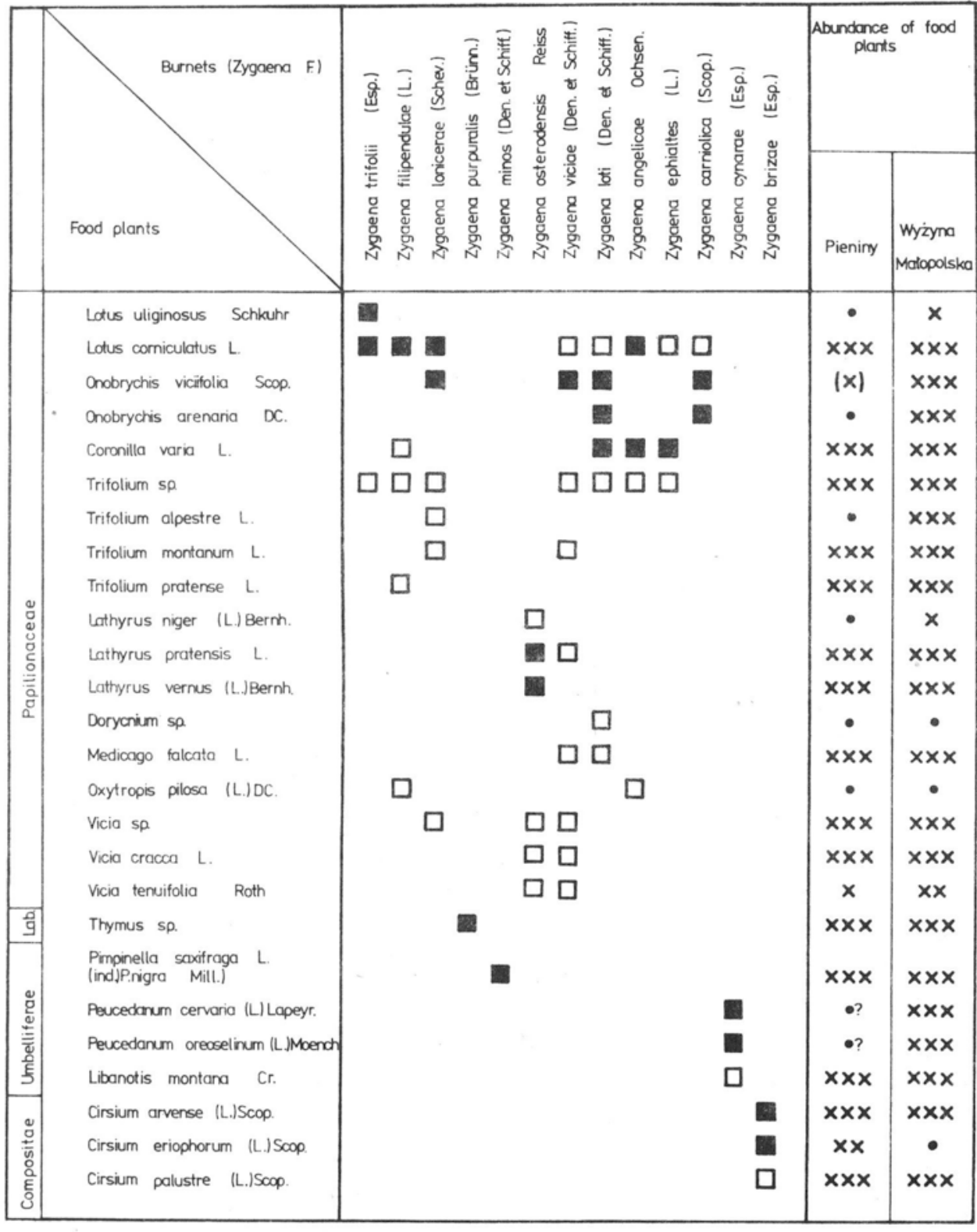

$\begin{array}{llllll}1 & \mathbf{2} 2 \times \times 3 & \times \times 4 & \times 5 & 0\end{array}$




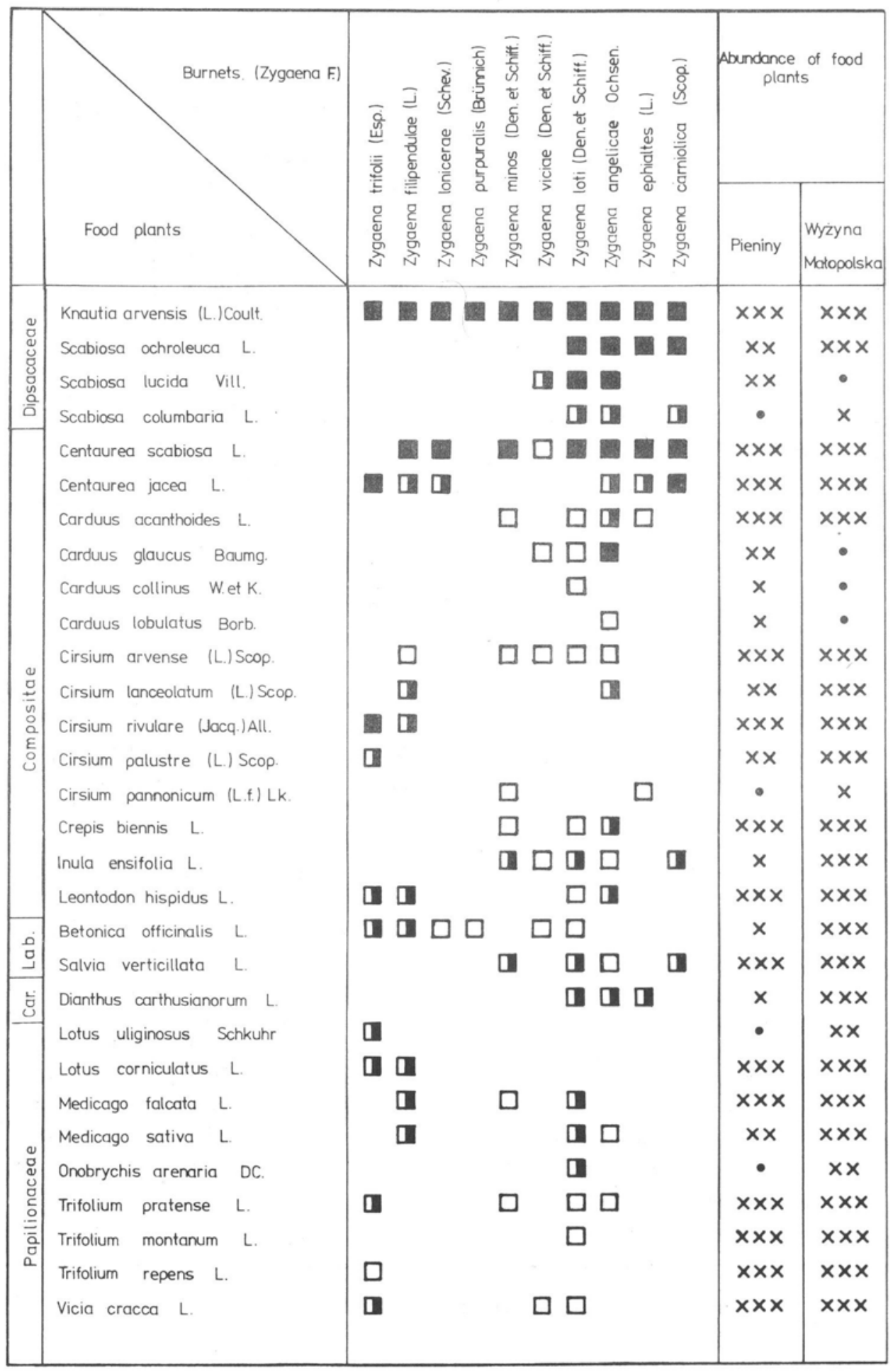


Mts. (rich limestone soils, Origano-Brachypodietum association). Here Zygaena angelicae Oschen. was dominant (up to 32 moths per $10 \mathrm{~min}$.). Z. loti (Den. et Schiff.) was less numerous, up to 16 moths per $10 \mathrm{~min}$., and Z. viciae (Den. et Schiff.), Z. filipendulae (L.) and Z. purpuralis (Brünn.)

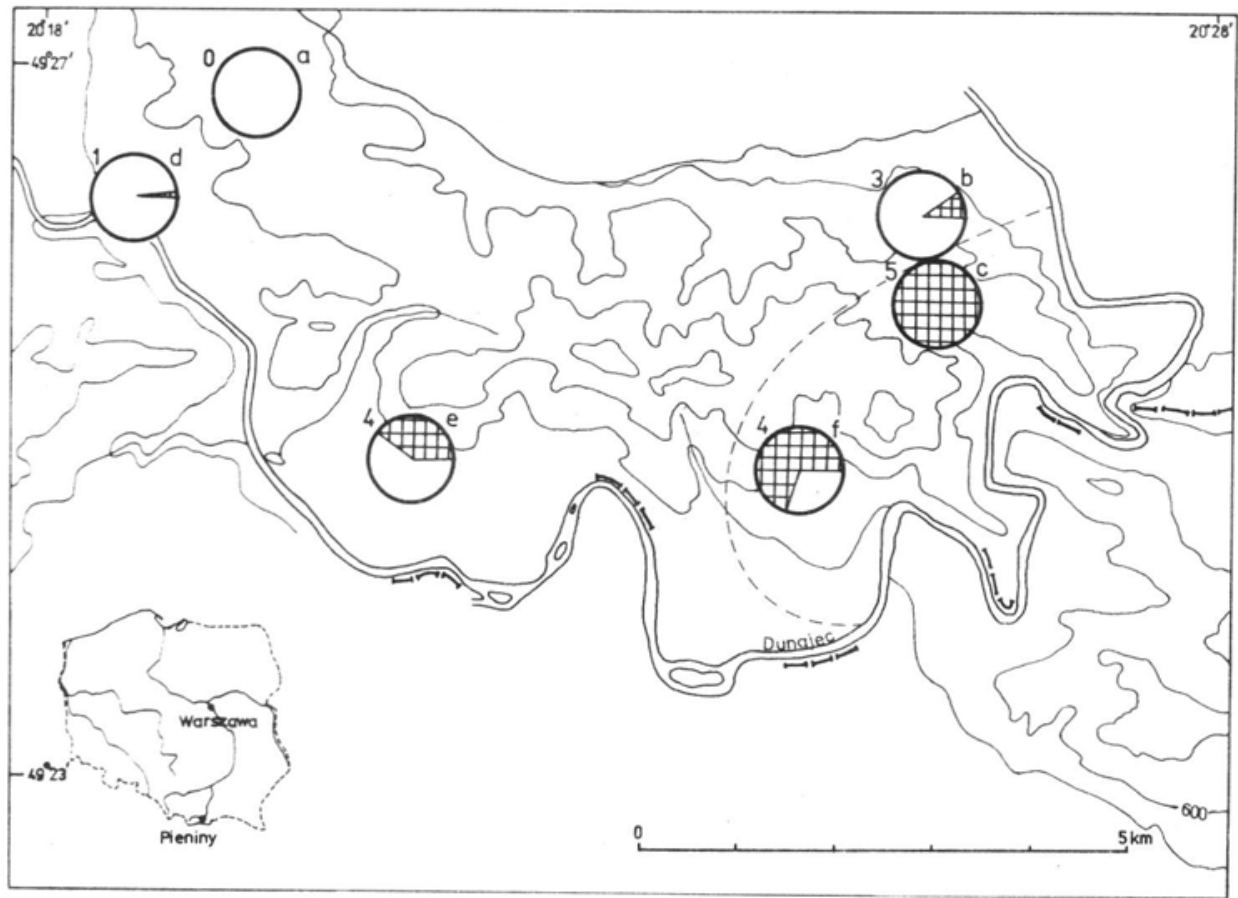

Fig. 1. Number of species and relative abundance of burnet-moths (Zygaena F.) in various biotopes of the Pieniny Mts. (cf. Table 3). a - cultivated fields and meadows; b - meadows utilized by farmers. situated at the borders of the PNP; c-meadows (Anthylli-Trifolietum) inside the PNP; d. e, f.-xerothermic plant community (Origano-Brachypodietum); dCzorsztyn; e-Cisowiec and Zamczysko; $f$ - Podskalnia Góra. The Arabic numerals by the circle indicates the number of burnet-moth species observed during our four-year study. The degree of hatching indicates the relative global abundance of the species of the genus Zygaena at the locality. The abundance at the locality "c" has been assumed to be $100 \%$

Table 2

A list of food-plants of Zygaena caterpillars in the Pieniny Mts. and Małopolska Uplands 1 - flowers of species visited most freauently 2 - flowers of species visited more rarely. 3 - flowers of species visited sporadically. 4 - common plant 5-fairly common plant. 6-rare plant. 7 - lacking 
occurred only locally. The specific composition was similar during the three seasons studied, only in 1982 the number of $Z$. angelicae Ochsen. was much higher than in the following years. whereas $Z$. loti (Den. et Schiff.) was more numerous only in 1983. In view of methodical difficulties

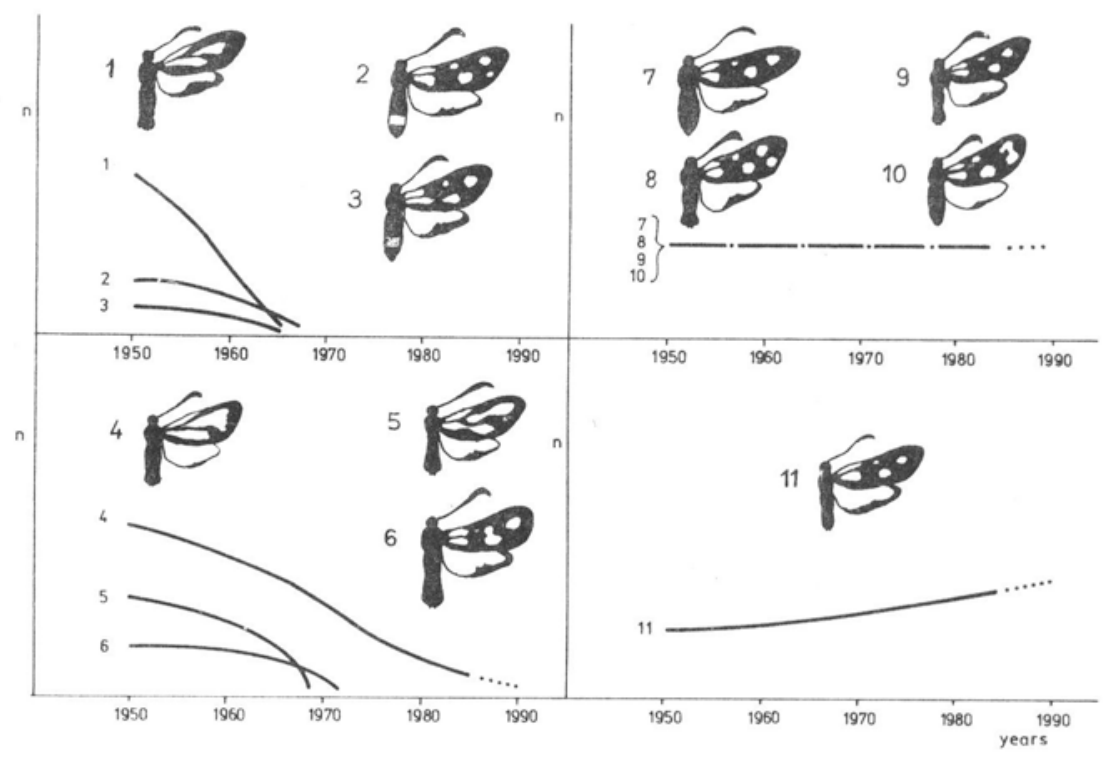

Fig. 2. An outline of population dynamics of the Zygaena F. species in the Pieniny Mts. in 1950-1985. The dashed line indicates the future trends if the habitat conditions do not undergo major changes. $1-Z$. brizae (Esp.). $2-Z$. ephialtes (L.). 3-Z. cynarae (Esp.) $4-Z$. purpuralis (Brünn.). $5-Z$ osterodensis Reiss, $6-Z$. trifolii (Esp.). $7-Z$. lonicerae (Schev.), $8-$ Z. filipendule (L.), $9-Z$. angelicae Ochsen., $10-Z$. loti (Den. et Schiff.) $11-$ Z. viciae (Den. et Schiff.)

which arise during the determining of the number of the moths under natural conditions, our observations permit us to make only general suggestions as to the dynamic tendencies of the Zygaena species under study (Fig. 2).

In the fifties of this century 11 species of the genus Zygaena occurred in the Pieniny Mts. In addition to the 6 species mentioned above, another 5 were reported. which despite extensive searches have not been found in this region since 1982. It must be assumed that no longer are they members of the contemporary fauna of the Pieniny Mts.. altough it cannot be ruled out definitively that one or some of them 
Table 3

Number of Zygaena F. imagines observed in different biotops in the Pieniny National Park in 1982-1985

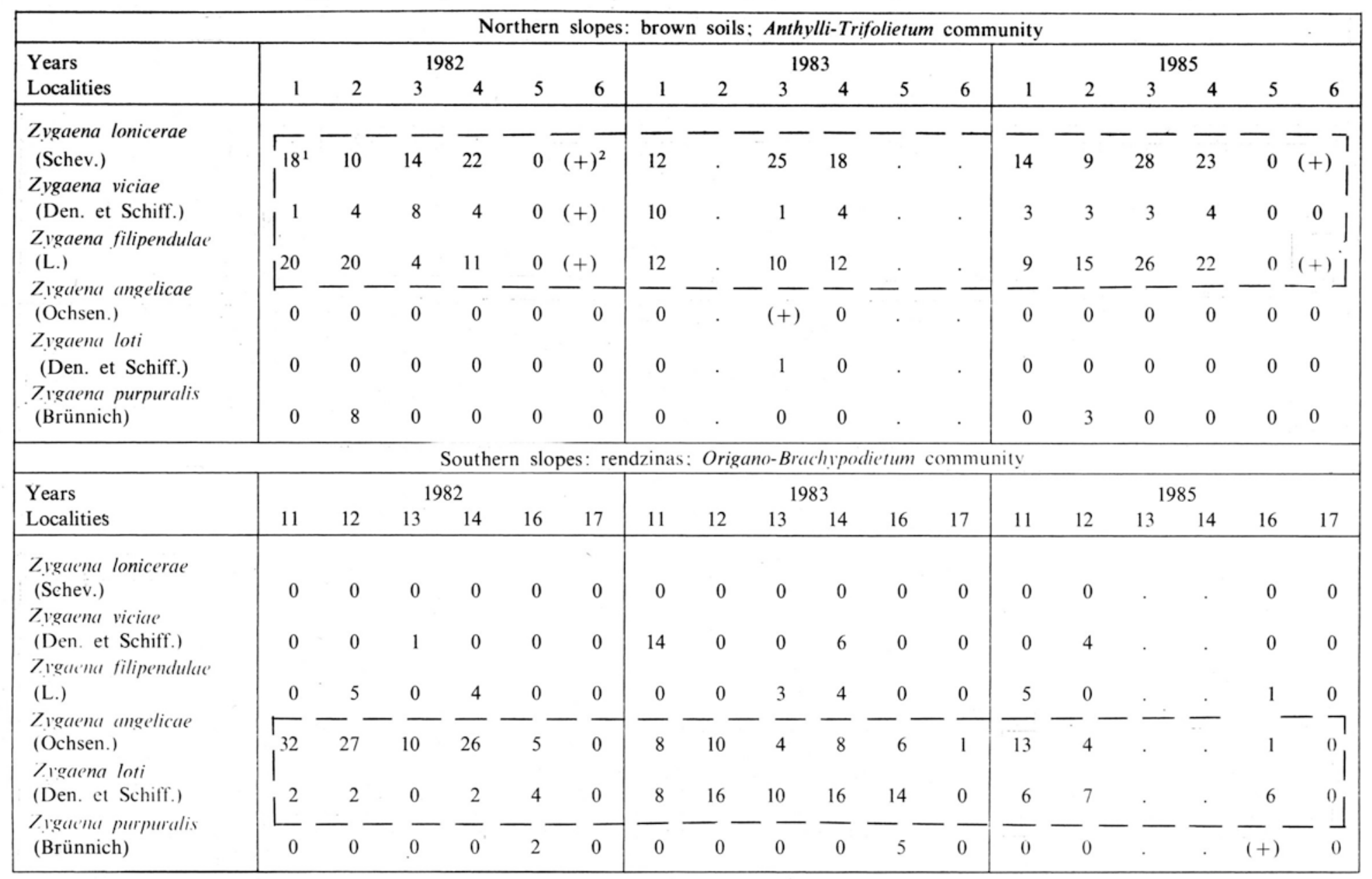

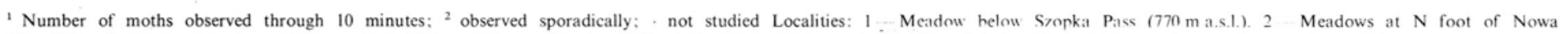

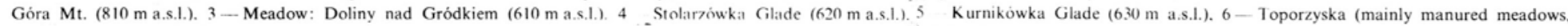

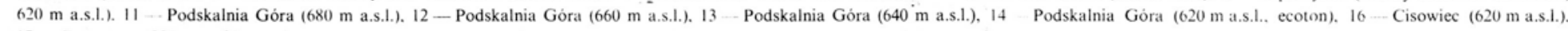
17 Czorsztyn (550 m a.s.l.) 


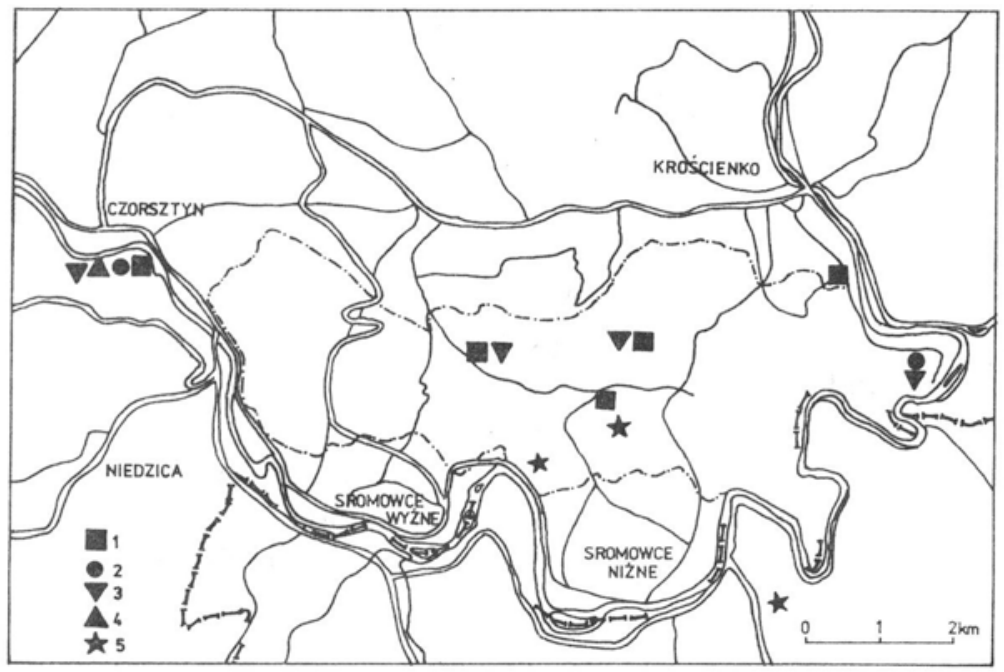

Fig. 3. The deserted localities of burnet-moths in PNP and its borders (species observed in 1950-1970). 1 - Z. trifolii (Esp.). 2 - Z. ephialtes (L.). 3 - Z. osterodensis Reiss, 4 Z. cynarae (Esp.). $5-Z$. brizae (Esp.)

may still appear there. The populations of the following species have vanished: Z. brizae (Esp.). Z. cynarae (Esp.), Z. ephialtes (L.), Z. osterodensis Reiss and Z. trifolii (Esp.) (Fig. 3).

AN ANALYSIS OF THE DATA CONCERNING THE OCCURRENCE OF FIVE ZYGAENA SPECIES IN THE PIENINY MTS. AND THEIR DISAPPEARANCE FROM THEM

\section{Zygaena brizae (Esp.)}

The specimens in J.S. Dąbrowski's collection come from the following sites:

Nowa Góra, $1947-1$ \&. leg. Miodoński; Nowa Góra, $1957-1$ ô, leg. Miodoński; Nowa Góra. 1959-1 ․ leg. Dąbrowski; Cervený Klàštor (Pieniny Mts. Slovakia), 1962 - 5 ôsô. 2 우. leg. Pruszyński; Cervený Klàštor, $1963-2$ ôô, 2 +q, leg. Pruszyński.

Błeszyński et al. (1965, p. 386) write that this species occurs in associations of saxicolous vegetation of the order Seslerietalia at Nowa Góra and Macelowa Góra; observed from the second half of June to the second half of July, not numerous; Stolarzówka Glade-1 specimen in a meadow in the first half of June. Larvae on Cirsium eriophorum at Nowa Góra. far more frequent than imagines (second half of May - second half of June). The species was recorded as outstandingly stenotopic from very small sites. several tens of square metres in area and distinctly 
xerothermic. They regard the finding of 1 individual in Stolarzówka Glade as accidental; according to Dąbrowski (1965. p. 143) the species was found in the Pieniny Mts. in 1947 by Miodoński. who captured one female in Nowa Góra. This locality was the only one in Poland where Z . brizae (Esp). was not scare. However since 1960 the species has probably become extinct. This phenomenon has also been observed in two other localities in the Pieniny Mts., in Macelowa Góra and near Trzy Korony Mts. Very likely the extinction of the species was caused by the over-collecting of the adults and caterpillars for several years by various lepidopterists. According to the available data, over 120 specimens of $Z$. brizae (Esp.) were collected in the Pieniny Mts. during five to six years. Of these about 60 specimens are present in the collections studied.

$Z$. brizae (Esp.) is an exceedingly rare species in Poland: Karpowicz (1930) mentioned it from the Sandomierz area and Holik (19:9) from the region of Przemyśl. It occurs in Moravia. Belanske Tatry Mts. and in the environs of Lvov (Dąbrowski 1965, p. 145). Also in Slovakia this southern species has only a few localities, in which however it is fairly numerous (Reiprich 1960, p. 299). In the area of Slovenský Rai Reiprich (1960) observed it at a small locality (a few areas) in 1949-1955. However the clearing was grown over later and the moths did not appear in following years.

The here presented materials show that $Z$. brizae (Esp.) occurred at Nowa Góra and Macelowa Góra in the Polish range of the Pieniny Mts. in 1947-1959 and it was still caught near Cervený Klàštor in their Slovakian range in 1962-1963. The populations were closely localized but fairly abundant. Meticulous searches made in 1982-1985 were fruitless. It should be assumed therefore that this species is quite extinct in the Pieniny Mts. The direct cause of the disappearance of the isolated locality at the edge of the distribution area may have been the overgrowth of the zone of Nowa Gora situated right below the summit and the excessive collecting of both their larvae and imagines. The larvae of Z brizae (Esp.) live on Cirsium arvensae; in the Pieniny Mts. they were observed and raised (R. Żukowski) on Cirsium eriophorum. In the Pieniny region Cirsium arvensae is common. whereas $C$. eriophorum fairly common (Grodzinska 1976, Zarzycki 1981). The food resources of the larvae of Z. brizae do not seem to have been reduced but the appropriate specific biotope does not exist any longer.

\section{Zygaena cynarae (Esp.)}

Specimens in J. S. Dąbrowski's collection: Zielone Skałki near Niedzica, $1952-2$ ôs. leg. Żukowski; Zielone Skałki. 1966 - 1 j̧. leg. Dąbrowski. 
Błeszyński et al. (1965, p. 386) write about a capture of a copulating couple on Scabiosa ochroleuca in an old clearing at Niedzice-Kosarzyska on 26 July 1952. Altough they quested for this rare species for a long time. they failed to find another specimen.

A small number of Pontian-Mediterranean localities of $Z$. cynarae (Esp.) are concentrated in Central Poland (Dąbrowski 1965. Romaniszyn and Schille 1929). This species was recorded from the Lesko region (Schramm 1948). from where however it has not been confirmed recently (Bielewicz 1973). It has been extinct in West Germany since 1952 (Blab and Kudrna 1982).

The Pieniny population of $Z$. cynarae (Esp.) was supposedly very small and confined to a small area owing to which it was not observed here until 1952. The main food-plants of its larvae. Peucedanum cervaria and $P$. oreoselinum, have not been met with in the study area lately (Grodzińska 1976. Zarzycki 1981); they were generally reported from the Pieniny Mts. in the 19 century (Berdau 1890. Gustawicz 1881) and from their Slovakian range (Flóra Slovenska 4, 1984). The larvae of $Z$. cynarae (Esp.) can live also on Libanotis montana, which grows all over the Central Pieniny Mts., but has not been noted from Zielone Skałki. where the above-mentioned species were caught. It may well be therefore that this small population of $Z$. cynarae (Esp.) died out because its food-plant vanished and these moths do not migrate over long distances.

\section{Zygaena ephialtes (L.)}

Specimens in J. S. Dąbrowski's collection:

Homole. 1951 - 1 ô, 1 †, leg. Dąbrowski; Kras. 1951 - 1 ô, leg. Dąbrowski; Zielone Skałki, 1967 - 1 ô, leg. Dąbrowski.

Sitowski (1910) found a specimen at Łupisko on 16 August 1907. Błeszyński et al. (1965) mention that it occurs singly in the Pieninki Range from the second half of July till the first half of August.

This species seems to have occurred in small numbers at lower altitudes throughout the Pieniny Mts. (Fig. 3). In spite of careful searches it was not observed before 1967. It must be assumed that the isolated Pieniny population of this moderately thermophilous species became extinct presumably between 1968 and 1981. The localities of Z. ephialtes (L.) were situated at the borders of the PNP, in the vicinity of urbanized areas and those exploited agriculturally increasingly intensively. The supposition arises that the cause of the dying-out of the population may have been progressing chemicalization and environmental changes (mineral fertilizers, pesticides). The resources of food-plants of both larvae and imagines are still large. although they have shrunk distinctly lately. 


\section{Zygaena osterodensis Reiss (Z. scabiosae Schev.)}

Specimens gathered by J. S. Dąbrowski in his collection:

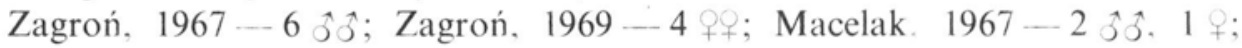
Macelak, 1969 - 3 ôô; Zielone Skałki. 1967 - 1 ô; Kosarzyska Glade near Niedzica. $1967-3$ ̧ैố; Kosarzyska Glade. $1969-1$ ô.

It was observed on the xerothermic slopes of Dhugi Gronik at the foot of the Pieninki Range on 5 and 13 July 1956 (Błeszyński et al. 1965). Dąbrowski (1965) encountered single specimens on Zagroń in 1957. 1959, 1973, 1975 and 1977. on Macelak in 1957 and 1959 and in Kosarzyska Glade near Niedzica in 1957.

This species. being strongly associated with woods. occurred in a number of localities on the northern slopes of the Pieniny Mts. It inhabites moderately wet sylvian meadows, thin and pretty well lighted woods vistas and clearings. The moths occur as a rule sparsely (singly), fairly large and numerous populations, e.g. like those in the Białowieża Forest, being rare. The flight of moths is limited to a distance of several hundred metres. A thin wood is not an impassable ecological barrier, as it is for most burnet-moths. In the Pieniny Mts. the food-plants of this species are supposedly Lathyrus vernus. not unfrequent in the woods on the southern slopes, and the species of the genus Vicia. common in this region.

In the case of $Z$. osterodensis Reiss it is especially difficult to indicate the factors responsible for the disappearance of this species from the Pieniny Mts. The resources of food-plants of both larvae and imagines seem to be abundant and intact. It may be supposed that the breakdown of the population was caused by the lately intensified fertilization of meadows and the use of pesticides.

\section{Zygaena trifolii (Esp.)}

Specimens gathered by J.S. Dabrowski in his collection:

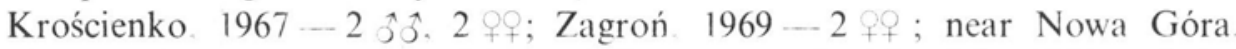

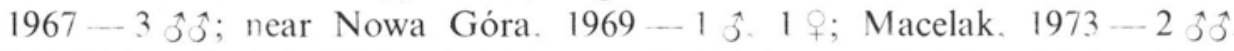
1 ; Zielone Skałki. $1967-1$ \&; Kosarzyska Glade near Niedzica 1967 - 3 ôs.

Sitowski (1906) was the first to report $Z$. trifolii (Esp.) from the Pieniny Mts. According to Błeszyński et al. (1965) this species occurs singly and very locally in wet meadows: Wyrobek Glade on 10 July 1949. Limierczyki Glade on 9 July 1947. Kosarzyska Glade near Niedzica on 15 July 1951 and Cyrlowe Skalki on 18 July 1957. The collection and information published so far show that in the past there were quite a number of localities of $Z$. Irifolii (Esp.) in the Pieniny Mts.. where however it was sought for in vain in 1981-1985. The authors observed 
a few specimens of this pecies in a complex of fens by the road from Niedzica to Łapsze Wyżne. Z. trifolii (Esp.) is a highly hygrophilous species and the main cause of its disappearance from the Pieniny Mts. is presumably a progressing decrease in the area of wet meadows and peatbogs and the fertilization of meadows. A similar phenomenon has occurred also in other regions, e.g. in the valleys of the Vistula and Rudawa river in the environs of Cracow.

\section{DISCUSSION}

The processes of extinction of plant and animals are continuously becoming more intense. As regards monophages the disappearance of a definite plant species result as it were automatically in the death of the animals closely associated with it. However. it is as a rule hard to tell which factors are responsible for the breakdown of a population in the natural state (Szarski 1976). Often it is even not enough to observe a vanishing specimen carefully to determine the causes of the extinction of the species living at large unambiguously: although a set of these causes would have seemed to be sufficiently well known. And so it is hard to attain certainty that we know all the circumstances inducing the dying-out of a population of the given species (in all the stages of individual development). It is still harder to assess the relative importance of the set of factors under study. Some investigators (e.g. Harcourt and Leroux 1967) think that the size of a population of the cabbage butterfly Pieris brassicae L. is governed exclusively by the degree of viral infection. Similarly, the size of a population of the small winter moth is thought to be limited by its infestation with a parasite and the abundance of Platella maculipennis and Spilonota ocellana is believed to be dependent exclusively upon the caprices of weather.

These views seem to be too radical and may refer merely o some synanthropic species, utilizing one-crop cultures of man. Regarding animals which are more loosely associated with human husbandry, the size of populations and their disappearance are probably subject to the action of far more differentiated agents.

In the temperate climatic region a set of meteorological factors which make up the weather of both a season of vegetation and a succession of years is of decisive importance. Once it favours the optimum development of a population of the given species. some other time it brings about a rise in the mortality rate of given developmental stadia (heat drought. cold and rainfall departing from the normal) or indirectly favours and stimulates the development of populations of fungal bacterial and viral parasites of insects. Nevertheless the predominant factor responsible for 
the vanishing of the populations of species living in a state of nature is the anthropopressure on the habitat (Dąbrowski and Krzywicki 1982, Blab and Kudrna 1982, Novàk and Spitzer 1982, Viedma and Bustillo 1976). This factor has probably been acting too short to cause negative (lethal) genetic trends, but it should not be belittle either. It follows from Van Valen's (1973) consideratios of the factors limiting the abundance of a species that if the abundance keeps on fluctuating within narrow limits for a fairly long time, then the limiting factors are linked by feedback with it. On the other hand, irregular and rapid changes indicate the dominant role of a factor which is independent of the size of the population.

Studies carried out in the PNP and at its borders show that the largest number of Zygaena species have persisted and their populations reach a relatively large size in the Central Pieniny Mts., in the area where xerothermic plant associations, much resembling natural ones, and non-fertilized mesophilous meadows of semi-natural character are preserved. The species whose localities had bordered upon urbanized areas disappeared (Fig. 3) and the size of populations of some other species shows a tendency to decrease (Zygaena purpuralis brünn.). Not only the species that have high environmental requirements (hygro- and thermophilous specis) but also mesophilous ones have withdrawn from the Pieniny Mts. As regards hygrophilous $Z$. trifolii (Esp.), the supposition arises that the progressive drainage of the region and the disappearance of moist meadows and peatbogs are responsible for the breakdown of its Pieniny population. In the case of two species it may be assumed that the decreasing food resources and microclimatic changes (overgrowth of biotope) have led to the vanishing of their populations, which were besides excessively exploited by lepidopterologists. In most cases, however, the food resources of both larvae and imagines of burnets are still fairly ample, even though they are shrinking continuously.

Under the circumstances of intensifying stresses (rapidly changing conditions) the animal components of the biocenosis, in our case the species of the genus Zygaena F., die out before their food-plants do. There are still many sites where the food-plants of larvae and imagines still occur in abundance but where there are no Zygaena species or other moths and butterflies, like Parnassius apollo (L.).e.g. in the proximity of the castle ruins at Czorsztyn. Increasing urbanization and the intensification of agriculture and forest management (mineral fertilization, insecticides, herbicides, contamination with heavy metals and sulphur, etc.) cause that in the PNP and at its borders the chemical composition of plants undergoes changes; young larvae of the moths are particularly sensitive to them. With regard to mechanisms which bring about the breakdown of a population we may only make suppositions. They may be, for instance. 
the intensification of parasitism in small, strictly localized populations, the development of non-specific parasites in very abundant synanthropic species, which parasites exterminate rare species as if en passant, and viral, bacterial or fungal diseases leading to the death of larvae enfeebled in consequence of their living on contamined food.

Within some 20 years 5 spesies of Zygaena $\mathrm{F}$. have become extinct in the Pieniny Mts.; the abundance of one species - $Z$. purpuralis (Brünn.) is on decrease and the population of $Z$. viciae (Den. et Schiff.) has been showing a tendency to increase slightly (Fig. 2). If the degradation of the Pieniny biotopes has not been stoped, we must be prepared for a further decrease in the number of burnets in the PNP and in the reserves in the Małopolska Uplands. Z. lonicerae (Schev.), Z. loti (Den. et Schiff.) and Z. angelicae Ochsen. will supposedly persist longest. In order to stop the dying-out of the Lepidoptera in the PNP the use of mineral fertilizers and chemicals should be reduced to a minimum in its area and in its direct surroundings. At the same time: 1) measures should be taken to counteract the overgrowing of clearings and xerothermic plant communities, 2) meadows should be mown late (in August) and 3) communication should be kept between small isolated islands of divided populations by the maintenance of passages for the Zygaena F. to move along (they fly only for short distances. up to several hundred meters). In view of the global changes of the environment there is unfortunately no guarantee that all these measures will stop the dying-out many animals when their refuges have been reduced to a minimum.

\section{REFERENCES}

Berdau F.. 1890. Flora Tatr. Pienin i Beskidu Zachodniego. Kasa im. J. Mianowskiego, Warszawa.

Bielewicz M.. 1973. Motyle większe (Macrolepidoptera) Bieszczadów Zachodnich i Pogórza Przemyskiego. Rocz. Muz. Górnośl. Bytom. Przyroda 7: 1-170.

Blab J., Kudrna O., 1982. Hilfsprogramm für Schmetterlinge. Naturschutz Aktuell 6: 5-135. Blaschke P. [s.a.]. Die Raupen Europas mit ihren Futterpflanzen. Ein vollständiger Raupenkalender nebst einer lepidopterologischen Botanik. Grasers Verl. (R. Liesche). Annaberg, Sachsen.

Błeszyński S.. Razowski J. Żukowski R. 1965. Fauna motyli Pienin. Acta Zool Crac. 10: 375-493.

Dąbrowski J.. 1959. Investigations on the attachment to a territory and the migrations of moths of the genus Zygaena Fabr. in the National Park of Oiców. Poland. Zesz. Nauk. UJ 23. Pr. Zool. 4: 105-131.

Dąbrowski J. S.. 1965. The variability of the species of the genus Zygaena F. (Lepidoptera: Zygaenidae) in Poland. Acta Zool. Crac. 10: 92-196.

Dąbrowski J. S., 1982. Przemiany we współczesnei lepidopterofaunie Pienin. In: Przyroda Pienin w obliczu zmian. Zarzycki K. (ed.). PWN. Warszawa-Kraków. p. 521-528. 
Dąbrowski J.S.. Krzywicki M.. 1982. Ginące i zagrożone gatunki motyli (Lepidoptera) w faunie Polski. Stud. Natur.. Ser. B. 31: 1-171.

Dzwonko 7.. Grodzińska K.. 1979. Numerical classification of epilithic and xerothermic communities in the Pieniny Mts. Fragm. Flor. Geobot. 25: 493-508.

Ehrendorfer F.. 1973. Liste der Gefässpflanzen Mitteleuropas. 2. erw. Aufl. G. Fischer. Stuttgart.

Flóra Slovenska. 1966-1984, 2-4/1. Veda. Vydav. SAV. Bratislava.

Grodzińska K. 1976. Rośliny naczyniowe Skalic Nowotarskich i Spiskich (Pieniński Pas Skałowy). Fragm. Flor. Geobot. 22: 43-127.

Gustawicz B.. 1881. Przyczynek do flory pienińskiei. Pam. Tow. Tatrz. 6: 1-23.

Harcourt D. G. Leroux E. J.. 1967. Population in insects and man. Amer. Sci. 55: 400-415.

Holik O. 1939. Rassenanalytische Untersuchungen an den in Polen vorkommenden Arten der Gattung Zygaena Fabr. (Lepidoptera). Ann. Mus. Zool. Pol. 12: 1-144.

Holik O. 1953. Die Nahrungspflanzen der Zygaenenraupen und ihre Bedeutung für die Unterleitung der Gattung Zygaena Fabr. Sonderdr.: Ent. Z. 62/63. 35 pp.

Karpowic7 S. 1930. Spis łuskoskrzydlych Ziemi Sandomierskiel. 3. Pol. Pis. Ent. 9: 13-32. Kinasz W. 1976. Ekologiczne podstawy urządzenia łąk w Pienińskim Parku Narodowym. Ochr. Przyr. 41: 77-118.

Koch M. 1964. Wir bestimmen Schmetterlinge. 2. Bären Spinner. Schwärmer und Bohrer Deutschlands (unter Ausschluss der Alpengebiete). 2. erw. Aufl. Neumann Verl. Radebeul u. Berlin.

Kostrakiewicz L. 1982. Klimat. In: Pryyroda Pienin w obliczu zmian. Zarzycki K. (ed.). PWN Warszawa-Kraków p. 53-69.

Michalik S. 1978. Rośliny naczyniowe Oıcowskiego Parku Narodowego. Stud. Natur. Ser. A. 16: 1-171.

Novák I. Spitzer K.. 1982. Ohroženy svet hmyzu. Ces. Akad. Ved. Prahaı.

Nowicki M.. 1870. Zapiski fauniczne. Spraw. Komis. Fizlogr. Tow. Nauk. Krak. 4: 1-28. Pancer-Koteiowa E. 1977. The nitrogen relation of the Pieniny meadows (Western Carpathians). Fragm. Flor. Geobot. 23: 363-408.

Razowski J.. 1985. Changes in the Lepidopterous fauna of Cracow. Poland. Nota Lepid. 8. 1: 65-68.

Reiprich A. 1960. Motýle Slovenska. Oblast Slovenskeho Raia. Slov. Akad. Ved. Bratislava. Romaniszyn J.. Schille F.. 1929. Fauna motyli Polski. Pr. Monogr. Komis. Fiziogr. PAU 6: 1-552.

Schramm W. 1948. Motyle okolic Olchowy Ziemi Sanockiei stwierdzone w okresie lat pięćdziesięciu. Pr. Komis. Mat.-Przyr. PTPN. (B) 10: 271-311.

Sitowski L. 1906. Motyle Pienin. Spraw. Komis. Fiziogr. AU 39: 39-69.

Sitowski L.. 1910. Motyle Pienin. Cz. 2. Spraw. Komis. Fiziogr. AU 44: 130-154.

S7arski H. 1976. Mechanizmy ewolucii. Wyd. 2 popr. i uzup.. Ossolineum. Wrockaw-Warszawa-Kraków-Gdańsk.

Van Valen L.. 1973. Pattern and the balance of nature. Evol. Theory 1: 31-49.

Viedma M. G.. Bustillo M. G. R.. 1976. Libro Rolo de los Lepidopteros Ibericos. Inst. Nac. Conserv. Natur. Madrid.

Zarzycki K.. 1981. Rośliny naczyniowe Pienin. Rozmieszczenie i warunki występowania. PWN Warszawa-Kraków. 
Rośliny pokarmowe kraśników (Zygaena $F$. Lepidopt., Zygaenidae) i wymieranie tych motyli w Pieninskim Parku Narodowym

\section{Streszczenie}

Rozpatrzono hipotezę. iż przyczyną 7mnieiszenia się liczby gatunków i liczebności populaci kraśników (Zygaena F.) w Pienińskim Parku Narodowym (PPN) mogą być zmiany bazy pokarmoweı tych motyli. Zestawiona lista roślin pokarmowych gąsienic kraśników w poludniowei Polsce liczy 26 taksonów (Papilionaceae. Umbelliferae, Compositae i Labiatae) (tab. 1). Dorosłe motyle (imagines) żeruią głównie na kwiatach roślin z rodziny Dipsacaceae i Compositae (tab. 2). W latach 1982-1985 na mezofilnych łąkach PPN obserwowano w drugiei połowie lipca latalące motyle: Zygaena lonicerae (Schev). Z. filipendulae (L.) i Z. viciae (Den. et Schiff.); kserotermiczne murawy na stokach południowych zasiedlaią głównie $Z$. angelicae Ochsen. i Z. loti (Den. et Schiff.); nieliczna iest obecnie w Pieninach $Z$. purpuralis (Bünn.) (incl. Z. minos (Den. et Schiff.)) (tab. 3. rys. 1). Zanikły populacie 5 gatunków kraśników które obserwowano w Pieninach w latach 1950-1960: Z brizae (Esp.). Z. cynarae (Esp.). Z. ephiates (L.). Z. osterodensis Reiss i Z. trifolii (Esp.) (rys. 2. 3). Zasoby roślin pokarmowych zarówno gąsienic lak i imagines kraśników są ieszcze w Pieninach i na Wyjynie Małopolskiei dość duże. lecz gwałtownie się kurczą w związku z postępuącą urbanizacıą $i$ intensyfikacią gospodarki rolneı. Przypuszczalnie przyczyną zmnieıszania się liczby gatunków i liczebności kraśników są w Pieninach i innych regionach kraıu gwałtowne 7miany biotopów (chemizacla środowisk. odwadnianie wilgotnych łąk i torfowisk. rozcłlonkowanie populacii) (Razowski 1985). W przypadku Z. brizae (Esp.) i Z. cynarae (Esp.) nasuwa się przypuszczenie. iż załamanie populacii mogło nastąpić w wyniku naruszania bazy pokarmoweı w związku z zarośniẹciem polany. Ogólny obraz dynamiki populacii gatunk w rodzaı Zygatena F. na terenie Pienin przedstawia rys. 2. Proces wymierania kraśników i innych motyli na obszarze Pienin można zahamować poprzez ochronę właściwych im biotopów: przeciwdziałać zarastaniu polan i kserotermicznych muraw późno kośić łąki oraz do minimum ograniczyć na terenie Parku i u lego granic stosowanie nawozów sztucznych i środków ochrony roślin (insektycydy herbicydy). 